\title{
Features of Transformation Processes in the Consumer Market in the Digital Economy
}

\author{
Petruchenya Irina Vladimirovna \\ Trade and economic Institute \\ FSBI of HE "Siberian Federal University" \\ Krasnoyarsk, Russia \\ petrucheny@gmail.com \\ Batraeva Elina Alexandrovna \\ Trade and economic Institute \\ FSBI of HE "Siberian Federal University" \\ Krasnoyarsk, Russia \\ ebatraeva@sfu-kras.ru
}

\author{
Batraev Marseille Dimekhametovich \\ Trade and economic Institute \\ FSBI of HE "Siberian Federal University" \\ Krasnoyarsk, Russia \\ md.sfu@mail.ru
}

\author{
Sartene Olga Tuktarovna \\ Trade and economic Institute \\ FSBI of HE "Siberian Federal University" \\ Krasnoyarsk, Russia \\ olga.sartene@yandex.ru
}

\begin{abstract}
Digitalization of priority sectors of the economy and the social sphere, including the consumer market, requires a qualitative review of the mechanism of interaction between market entities and the use of new tools for regulating their relationships. Globalization of the consumer market in the digital economy leads to a significant change in consumer preferences, affects the composition of market participants, information becomes the main factor affecting the formation of demand.

In this regard, there is a need for further development of a scientific methodology for the functioning of the digital economy within the global economic system of the consumer market, which ensures the interaction of the state, producers, and consumers in order to increase its effectiveness

The aim of the research is to study the processes of economic transformation in the context of digitalization and their impact on the development of the consumer market. The article outlines modern approaches to the study of the transformational process of market functioning. On the base of the parametric approach, ongoing changes in the relations of market participants were identified, the influence of globalization factors on the development of the needs of the consumer market was revealed. The result of the study is the creation of an information basis for modeling the parameters of the assessment of the consumer market in the digital economy.
\end{abstract}

Keywords: consumer market, digital economy, parameters, identification, transformation, basic determinants, market types, market structure, consumer behavior

\section{INTRODUCTION}

The transformation processes taking place in the economic system reflect the needs of society in changes while slowing down the development process. They are aimed at overcoming the discord between the inertia of the development of socio- economic relations and the qualitative nature of the changes. Transformation as a kind of socio-economic transformation occurs without qualitative shifts in the initial state of the system, but is characterized only by a change in its formal or quantitative features. In modern conditions, the study of transformation processes in the consumer market is of particular interest, since this market is an essential element of the economic system, and its state reflects all the changes taking place in socio-economic systems and society.

The relevance of the topic and determined the choice of the research vector, the purpose of which is to identify and study the characteristics of the transformation processes taking place in the consumer market of the Russian Federation.

To achieve this goal, methodological approaches to the study of the consumer market were studied on the basis of which a parametric approach was preferred; identified indicators, characteristics and processes that are considered as parameters of the consumer market, disclosed the transformation of these parameters, processes in digital space

\section{LiterAtURE REVIEW AND RESEARCH METHODS}

An analysis of current studies on the transformation of the consumer market in the digital economy shows that the 
relevance of this subject of attention is motivated by the strengthening of globalization processes, the vigorous development of information technologies. The process of market transformation in many cases is associated with the destruction of sustainable patterns of interaction, allelopathy of market residents $[1,2,3,4,5,6,7]$

So, according to $\mathrm{M}$. Dvoryashina the transformation of the market is "the transformation of the market structure, forms and functions of the market, leading to a change in the goals of market participants." Market modification is a chronology of cycles of state change within the cycle, with a jump-like transition of the state at the end of the cycle to a new qualitative level, which marks the beginning of a new development cycle. [1]. Highlighting the main features of a digital society, Don Tapscott emphasizes that the key focus is on the orientation to knowledge, the digital form of representing objects, the virtualization of production, the elimination of intermediaries in the markets, the transformation of manufacturer-consumer relations, dynamism, globalization, etc. [8].

The methodological basis for studying the transformation of the consumer market in the economic literature, as a rule, is historical [9, 10, 11], system [8, 12, 13, 14, 15], information [1, 12, 16, 17], innovative approaches [16, 17, 18, 19]. Nevertheless, modern economic literature does not reflect generally accepted criteria and parameters for research, evaluation of transformation processes, and the richly expanding, complicated structure of the consumer market. Of particular interest is the proposed Shakhova OA [20] typology of the consumer market through components - degree of territorial localization, industry characteristic, nature of exchange, market subjects and objects, level of saturation.

Empirical methods, such as dynamic observation, description, comparison, were used as research tools, tabular and graphical methods of information visualization were used.

\section{RESULTS}

Evaluation of the consumer market implies the possibility of establishing its state, the significance of indicators for existing or emerging entities, cost or quality characteristics, which is expressed by the concept of "parameters". In this regard, the theoretical platform of the study is based on a parametric approach that allows identifying the presence of transformation processes in the consumer market through such parameters as the basic determinants of the consumer market, objects, subjects, market types, its competitive structure, indicators of state and development characteristics, consumer behavior and government regulation. To study this process, the parameters were grouped into seven blocks (Fig. 1).

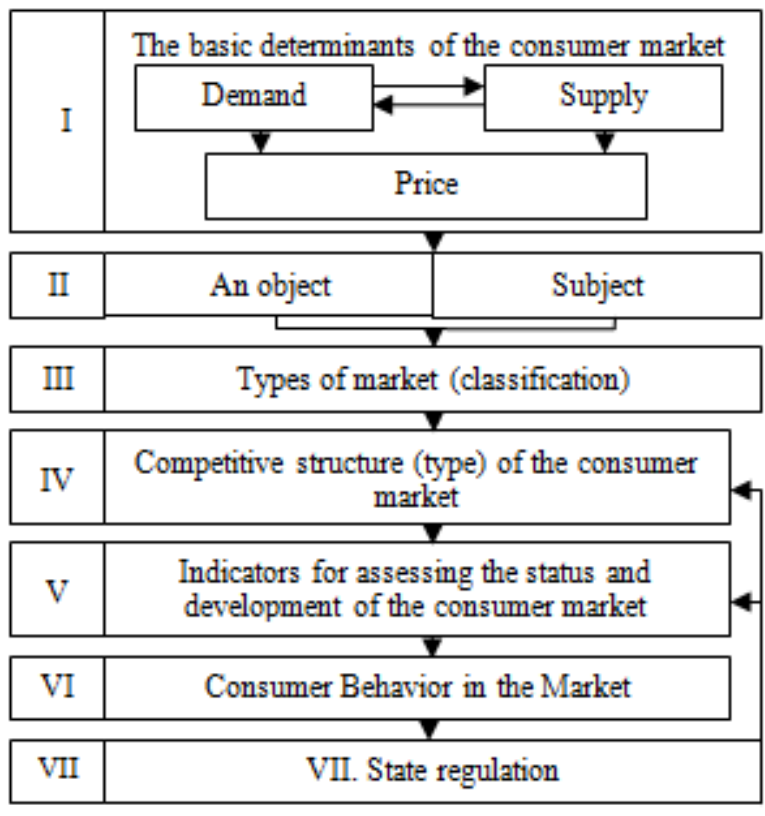

Fig. 1. Key parameters for the identification of transformation processes in the consumer market

1. The traditional basic determinants of the consumer market in a market economy of any type are demand, price, and supply. But in the digital economy, information begins to act as the most important resource in relation to the main determinants of the market (Fig. 2.) - it can largely replace them, significantly affect their volume and structure ... "The concepts that people hold in their heads and the quality of the information available to them determine the success or failure of the entire enterprise" [17].

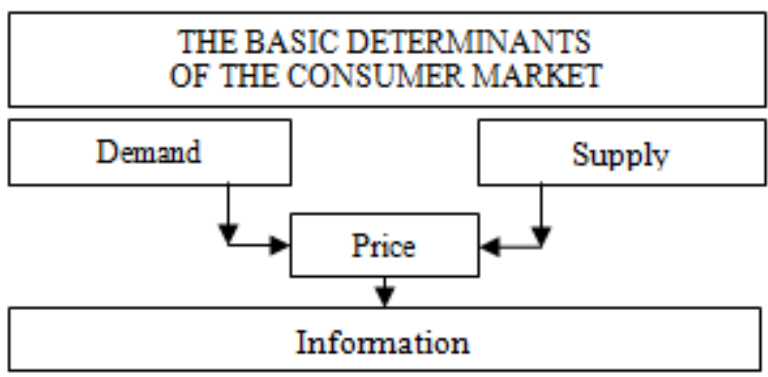

Fig. 2.

The universality and integrity of the impact of information on the development of the economy, including the consumer market, made it possible to speak of it as a leading factor in economic growth, "... a new paradigm of economic growth" [21].

The advancement of information as a determining resource allows us to abandon the traditional opposition of types of economic growth: through the use of information resources, they can be considered both intensive and extensive at the same time.

2. The objects and subjects of the consumer market are also transforming in the digital economy. In addition to 
4. Traditionally, in the classical economic literature, the traditional subjects - sellers (trading, catering, financial organizations, etc.) buyers (households, entrepreneurs, organizations, etc.) there are digital consumers: consumers of digital informational tangible goods, digital manufacturers (online stores, digital supermarkets, etc.), and digital platforms. The composition of the consumer market objects is expanding: they are supplemented by digital information products (digital products), intangible electronic goods that do not have physical embodiment, are available to the consumer for free or for free directly in the Internet information space.

3. The transformation of the consumer market is associated with servicing the sphere of personal consumption of the population. It is a complex system. In this regard, the composition and structure of the consumer market is traditionally classified: in accordance with a regional attribute (local, regional, national world); by appointment (market of goods and services); depending on the implementation channels (organized and unorganized); by participants (market of buyers, sellers, government agencies, intermediaries, etc.). Global changes in the economy also affected the formats of the consumer market (Table I).

TABLE I. TRANSFORMATIONAL FEATURES OF THE CLASSIFICATION OF THE CONSUMER MARKET BY TYPE IN THE DIGITAL ECONOMY

\begin{tabular}{|c|c|c|c|}
\hline \multicolumn{4}{|c|}{ Types of Consumer Market } \\
\hline $\begin{array}{l}\text { Regional } \\
\text { sign }\end{array}$ & $\begin{array}{c}\text { Market } \\
\text { purpos } \\
e\end{array}$ & Sales channels & Members \\
\hline $\begin{array}{l}\text { Sales } \\
\text { opportun } \\
\text { ities } \\
\text { expand } \\
\text { in terms } \\
\text { of use } \\
\text { E- } \\
\text { commerc } \\
\text { e that } \\
\text { drives } \\
\text { change: } \\
\text { local, } \\
\text { regional } \\
\text { markets } \\
\text { are } \\
\text { turning } \\
\text { into } \\
\text { global }\end{array}$ & $\begin{array}{l}\text { Mass } \\
\text { markets } \\
\text { give } \\
\text { way to } \\
\text { many } \\
\text { markets } \\
\text { with } \\
\text { small } \\
\text { capaciti } \\
\text { es and } \\
\text { differen } \\
\text { tial } \\
\text { product } \\
\text { require } \\
\text { ments }\end{array}$ & $\begin{array}{l}\text { Digital platforms are } \\
\text { being created: } \\
\text { infrastructure } \\
\text { (providing IT services } \\
\text { and information for } \\
\text { decision making) and } \\
\text { applied (sharing } \\
\text { economic values on the } \\
\text { market). Build market } \\
\text { relationships by type } \\
\text { B2C and B2B. B2C is } \\
\text { a market sector focused } \\
\text { on end users of } \\
\text { products (general } \\
\text { nutrition (traditional } \\
\text { and food substitutes), } \\
\text { and personalized } \\
\text { (group and } \\
\text { individual)). B2B is a } \\
\text { market sector focused } \\
\text { on the organization of } \\
\text { interaction between } \\
\text { companies in the } \\
\text { process of production } \\
\text { and sale of food } \\
\text { products. The chain of } \\
\text { "intermediaries" is } \\
\text { reduced a }\end{array}$ & $\begin{array}{l}\text { Individual } \\
\text { market } \\
\text { participan } \\
\text { ts are } \\
\text { formed } \\
\text { with a } \\
\text { specific } \\
\text { set of } \\
\text { requireme } \\
\text { nts for the } \\
\text { product } \\
\text { and price. } \\
\text { New } \\
\text { participan } \\
\text { ts: } \\
\text { informati } \\
\text { on } \\
\text { providers, } \\
\text { operator } \\
\text { and } \\
\text { platform } \\
\text { developer } \\
\text { developer } \\
\text { s and } \\
\text { consumer } \\
\text { s of IT } \\
\text { services }\end{array}$ \\
\hline
\end{tabular}
consumer market is divided into four types of market models, depending on the existing obstacles to entry and exit; the number of sellers, buyers; degree of differentiation of goods; diversification opportunities; the influence of sellers on the price level, price behavior. The globalization and functioning of digital platforms smooth or eliminate the boundaries of classifying a market as a result of the availability in the digital environment of any information about sellers, goods, services, prices, a geographically unlimited number of market participants, and virtually no barriers to entering the market. Thus, this typification of the market loses its meaning, is being modified, while the level of competition is increasing due to the possibility of free placement in the network space of information on the supply of goods and services.

5. The condition and development of the consumer market can be assessed by a set of indicators characterizing various aspects of its functioning. In the context of the digital economy, approaches to the formation and interpretation of indicators characterizing the market are also being modified; their role in evaluating and their value are changing (Table 2).

TABLE II. MODIFICATION OF THE INTERPRETATION OF INDICATORS CHARACTERIZING THE CONSUMER MARKET

\begin{tabular}{|c|c|c|}
\hline $\begin{array}{l}\text { Indicator } \\
\qquad \\
\text { character } \\
\text { izing the } \\
\text { market of } \\
\text { goods and } \\
\text { services } \\
\end{array}$ & Analog Economy & Digital economy \\
\hline \multicolumn{3}{|c|}{ Market situation indicators } \\
\hline $\begin{array}{l}\text { Market } \\
\text { accessibili } \\
\text { ty }\end{array}$ & $\begin{array}{l}\text { It is perceived from } \\
\text { the point of view of } \\
\text { the geographical } \\
\text { position of the } \\
\text { market: distance, } \\
\text { transport } \\
\text { accessibility, cost of } \\
\text { moving goods, } \\
\text { import regulation } \\
\text { system (restrictions, } \\
\text { duties, etc.) }\end{array}$ & $\begin{array}{l}\text { Marketplaces on the } \\
\text { Internet are not } \\
\text { limited, there are no } \\
\text { natural and } \\
\text { institutional } \\
\text { obstacles. } \\
\text { Availability } \\
\text { Increases } \\
\text { Significantly }\end{array}$ \\
\hline $\begin{array}{l}\text { Market } \\
\text { cycle }\end{array}$ & $\begin{array}{l}\text { Market conditions } \\
\text { characterized by } \\
\text { seasonal } \\
\text { fluctuations of } \\
\text { various durations; } \\
\text { market cycles } \\
\text { dictated by the laws } \\
\text { of a market } \\
\text { economy }\end{array}$ & $\begin{array}{l}\text { Seasonal } \\
\text { fluctuations due to } \\
\text { seasonality of } \\
\text { production and } \\
\text { consumption cease } \\
\text { to affect the market } \\
\text { situation }\end{array}$ \\
\hline $\begin{array}{l}\text { Market } \\
\text { condition }\end{array}$ & $\begin{array}{l}\text { It is characterized } \\
\text { by the ratio of } \\
\text { supply and demand, } \\
\text { which determines } \\
\text { the saturation of the } \\
\text { market with goods, } \\
\text { the degree of } \\
\text { satisfaction of } \\
\text { demand, breadth, }\end{array}$ & $\begin{array}{l}\text { The use of } \\
\text { cyberspace provides } \\
\text { an opportunity to } \\
\text { reduce the time for } \\
\text { a new product to } \\
\text { enter the market, } \\
\text { increases the degree } \\
\text { of production } \\
\text { flexibility, improves }\end{array}$ \\
\hline
\end{tabular}




\begin{tabular}{|l|l|l|}
\hline $\begin{array}{l}\text { Cost } \\
\text { effectiven } \\
\text { ess }\end{array}$ & $\begin{array}{l}\text { Economic } \\
\text { efficiency - an } \\
\text { indicator } \\
\text { determined by the } \\
\text { ratio of economic } \\
\text { effect and costs that } \\
\text { give this effect }\end{array}$ & $\begin{array}{l}\text { Lower costs, the } \\
\text { possibility of a } \\
\text { sharp increase in } \\
\text { sales without } \\
\text { increasing material } \\
\text { costs leads to } \\
\text { increased profits, } \\
\text { market efficiency }\end{array}$ \\
\hline $\begin{array}{l}\text { Social } \\
\text { performan } \\
\text { ce }\end{array}$ & $\begin{array}{l}\text { Social efficiency - } \\
\text { the degree of } \\
\text { expectation of ability to meet } \\
\text { people's interests } \\
\text { and needs that has } \\
\text { been put into } \\
\text { practice }\end{array}$ & $\begin{array}{l}\text { The emerging needs } \\
\text { in the short term } \\
\text { with minimal time, } \\
\text { money. }\end{array}$ \\
\hline
\end{tabular}

\begin{tabular}{|c|c|c|}
\hline & $\begin{array}{l}\text { completeness, } \\
\text { assortment } \\
\text { structure, quality of } \\
\text { goods. }\end{array}$ & $\begin{array}{l}\text { product quality, } \\
\text { leading to increased } \\
\text { competitiveness of } \\
\text { the industry }\end{array}$ \\
\hline $\begin{array}{l}\text { Market } \\
\text { Condition } \\
\mathrm{s}\end{array}$ & $\begin{array}{l}\text { They are formed } \\
\text { under the influence } \\
\text { of market } \\
\text { conditions and } \\
\text { prices, determined } \\
\text { by the level of cash } \\
\text { income of } \\
\text { consumers and } \\
\text { competition, the } \\
\text { degree } \\
\text { development of the } \\
\text { distribution } \\
\text { network, etc. }\end{array}$ & $\begin{array}{l}\text { Small organizations } \\
\text { are able to compete } \\
\text { with larger market } \\
\text { players. }\end{array}$ \\
\hline \multicolumn{3}{|c|}{ Market Infrastructure Indicators } \\
\hline $\begin{array}{l}\text { Communi } \\
\text { cation and } \\
\text { Informatio } \\
\mathrm{n}\end{array}$ & $\begin{array}{l}\text { The main means of } \\
\text { communication in } \\
\text { the consumer } \\
\text { market are } \\
\text { advertising, sales } \\
\text { promotion, personal } \\
\text { sales, public } \\
\text { relations, direct } \\
\text { marketing }\end{array}$ & $\begin{array}{l}\text { Search engines, } \\
\text { sharing platforms, } \\
\text { e-commerce } \\
\text { platforms, social } \\
\text { networks globally } \\
\text { transform the } \\
\text { market, become } \\
\text { drivers of economic } \\
\text { growth, innovation } \\
\text { and competition }\end{array}$ \\
\hline $\begin{array}{l}\text { Sales } \\
\text { channels }\end{array}$ & $\begin{array}{l}\text { A number of legal } \\
\text { and (or) individuals } \\
\text { involved in the } \\
\text { process } \\
\text { promoting goods } \\
\text { from producer to } \\
\text { consumer }\end{array}$ & $\begin{array}{l}\text { The emergence of a } \\
\text { spatial model } \\
\text { consisting of market } \\
\text { participants that are } \\
\text { the target audience } \\
\text { in the global cyber } \\
\text { network, digitized } \\
\text { product and method } \\
\text { of implementation } \\
\text { through electronic } \\
\text { commerce, Internet } \\
\text { banking, digital } \\
\text { marketing }\end{array}$ \\
\hline \multicolumn{3}{|c|}{ Purchasing Power Indicators } \\
\hline $\begin{array}{l}\text { Market } \\
\text { volume }\end{array}$ & $\begin{array}{l}\mathrm{E}=\mathrm{P}+\mathrm{I}-\mathrm{E}+\mathrm{Z}, \\
\text { where } \mathrm{P} \text { is the } \\
\text { production of the } \\
\text { resource; } \\
\text { And, } \mathrm{E}-\text { import and } \\
\text { export of a resource; } \\
\mathrm{Z} \text { - stocks. }\end{array}$ & $\begin{array}{l}\text { Determined by the } \\
\text { size of the digital } \\
\text { platform }\end{array}$ \\
\hline $\begin{array}{l}\text { Market } \\
\text { balance }\end{array}$ & $\begin{array}{l}\text { It is characterized } \\
\text { by the degree to } \\
\text { which the needs of } \\
\text { society are provided } \\
\text { with resources. The } \\
\text { totality of resources } \\
\text { is compared with } \\
\text { the volumes, } \\
\text { directions of their } \\
\text { use, which can lead } \\
\text { to deficit, } \\
\text { overproduction or } \\
\text { equilibrium. }\end{array}$ & $\begin{array}{l}\text { The scope of } \\
\text { operations is limited } \\
\text { only by the size of } \\
\text { the Internet. }\end{array}$ \\
\hline \multicolumn{3}{|c|}{ Market performance indicators } \\
\hline
\end{tabular}

6. Consumer behavior in the market is determined by many factors that scientists classify according to various criteria, highlighting - external, internal, cultural, social, personal, psychological, individual, organizational, economic, etc. These issues are described in detail in the works of researchers [9, 22, 23, 24, 25, 26, 27, 28]. Of course, the era of globalization affects consumer behavior, incentives for consumption, and the ability to obtain information, the timing of the implementation of customer decisions. Under these conditions, the maximum individualization of the interaction of market entities (sellers and buyers) occurs with a completely independent choice of communication channels with each other (Table 3 ).

TABLE III. CONSUMER BEHAVIOR IN A DigitAL ECONOMY

\begin{tabular}{|c|c|c|}
\hline \multicolumn{3}{|c|}{ Consumer behavior } \\
\hline $\begin{array}{l}\text { Modification of } \\
\text { the behavior of } \\
\text { market } \\
\text { participants }\end{array}$ & $\begin{array}{c}\text { Transformation } \\
\text { of consumer } \\
\text { shopping } \\
\text { motivation }\end{array}$ & $\begin{array}{c}\text { Lifecycle } \\
\text { Transformation } \\
\text { Needs }\end{array}$ \\
\hline $\begin{array}{l}\text { The power of the } \\
\text { digital economy is } \\
\text { changing consumer } \\
\text { habits. The priority } \\
\text { is the relationship } \\
\text { between sellers and } \\
\text { buyers via the } \\
\text { Internet. The goal } \\
\text { of sellers is to } \\
\text { consolidate the } \\
\text { maximum possible } \\
\text { information about } \\
\text { customers, which } \\
\text { allows them to } \\
\text { predict their } \\
\text { behavior, loyalty } \\
\text { and trust in } \\
\text { products. }\end{array}$ & 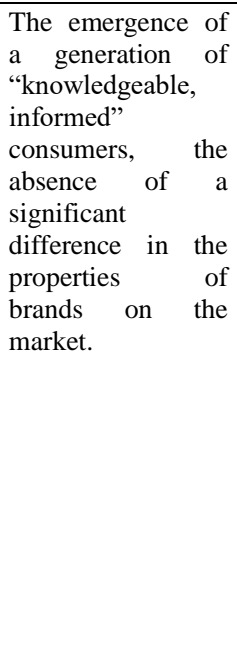 & $\begin{array}{l}\text { The growth rate of } \\
\text { meeting needs. Moral } \\
\text { deterioration is ahead of } \\
\text { physical deterioration. } \\
\text { Specific socio- } \\
\text { economic mechanisms } \\
\text { for regulating } \\
\text { consumption relations } \\
\text { are being formed. } \\
\text { Changing the type of } \\
\text { relations ans } \\
\text { interactions of subjects } \\
\text { in the market based on } \\
\text { electronic network } \\
\text { communication }\end{array}$ \\
\hline
\end{tabular}

7. In the analogue economy, the consumer market operates subject to regulation by the state, the main methods of which are antitrust, tax, customs legislation, policies in the field of 
cash income of the population, compliance with its rights, investments, benefits, etc. The transition to a digital economy requires a qualitative change in legislation, that is, the creation of a regulatory framework that takes into account: the virtual absence of borders between countries in the digital space; free access to information on prices and parameters of goods and services; the possibility of instant comparison; unlimited number of buyers and sellers; the difficulty of tracking sales volumes of goods and services for tax purposes; reduced sellers' responsibility for quality and safety; increasing the risk of violation of consumer rights, etc. Thus, the transformation processes should be objectively accompanied by legislative changes that allow leveling emerging risks and taking into account new conditions for the functioning of consumer market entities.

\section{DISCUSSION}

Domestic and foreign authors have proposed many approaches to the study and evaluation of changes in the consumer market in modern conditions, reflecting the different facets of this process, in a certain sense complementing and concretizing each other. The results of the studies indicate that, along with historical, integrated and other approaches, the proposed author's approach to the study of transformational processes is of particular interest.

A parameter is a quantity characterizing the basic property of a system or process. In this context, in relation to this article, the parameters act as identifiers that have specific characteristics and are used for quantitative, qualitative, as well as comparative assessment of the modification processes occurring in the consumer market in the digital economy.

As fundamental parameters, the article suggests the basic determinants of the market, market objects and subjects, its types and types, consumer behavior, indicators characterizing the state of the market, as well as methods of state regulation.

The proposed approach allows using empirical methods to conduct research and comparison of the selected parameters in development, taking into account causal relationships. The stated results of the study can serve as information support for modeling the parameters of the assessment of the consumer market in the digital economy, as well as contribute to the growth of the efficiency of its functioning both in general and its individual segments in particular.

\section{CONCLUSION}

A study of the consequences of transformational processes in the consumer market shows that currently, in the context of digitalization, it is necessary to adjust existing approaches to the study of the consumer market. In the process of the study, the need to study a parametric approach to research was substantiated, the parameters that underwent a significant transformation in modern conditions were identified, reviewed and studied, which will complement the existing ones and develop new models and methods for studying the consumer market in the Russian Federation. This will help to understand the processes taking place on it; increase the efficiency of its functioning.

\section{REFERENCES}

[1] M.M. Dvoryashina, "Transformation of the branch market: approaches to modeling", Modern researches of social problems (electronic scientific journal), vol. 1(09), 2012.

[2] O.V. Fetisova, T.V. Chigareva, "Theoretical bases of functioning of the regional consumer market", Business. Education. Right, vol. 2(31), 2015, pp. 52-56.

[3] V.V. Kurchenkov, O.V. Fetisova, T.V. Chigareva, "Expansion of network companies in the regional consumer market: trends and consequences", Bulletin of Astrakhan state technical University. Series: Economics, vol. 1, 2013, pp. 83-89.

[4] I.V. Petruchenya, Z.A. Vasilyeva, "Transformation of the process of consumption in the digital economy", Science and business: ways of development, vol. 11(101), 2019.

[5] E.L. Ralnikova, "Trade as a mechanism of the consumer market", Economics and entrepreneurship, vol. 2(58), 2015, pp. 1086-1090.

[6] T.N. Savina, "Digital economy as a new paradigm of development: challenges, opportunities and prospects", Finance and credit, vol. 24(3), 2018, pp. 579-590.

[7] N.V. Usova, "Methodical approaches to the study of local consumer markets of large cities (on the example of cities of industrial regions of the Urals)", Regional economy: theory and practice, vol. 31(358), 2014, pp. 14-23

[8] V.K. Stepanov, "the Age of network intelligence: about don Tapscott's book "Electronic digital society", Information society, vol.2, 2001, pp. 67-70.

[9] I.V. Kuznetsova, "Changing the model of consumer behavior in Russia and the consumer market", Scientific and methodological electronic journal "Concept", vol. 31, 2017, pp. 1406-1410.

[10] T.I. Stavtseva, "The Place and role of information resources in the modern economy", Scientific notes of the Orel State University. Series: Humanities and social Sciences. Oryol state University. I. S. Turgeneva (Eagle), vol. 3(37), 2010, pp. 37-44.

[11] L.P. Stebakova, The Transformation of economic systems: theory and practic, author's abstract of doctor of economic Sciences, 2010, p. 55.

[12] P. Kotler, Marketing Moves: A New Approach to Profits, Growth, and Renewal, 2002, p. 7.

[13] K. Rakhmatulina, "Transformation model of consumer choice in the modern economy", Economic science, vol. 87, 2012, pp. 24-27.

[14] E.Yu. Miroshina, "Models of consumer behavior in modern Russia [Electronic resource]", Scientific methodical electronic journal "Concept", vol. 13, 2015, pp. 1806-1810.

[15] M.Yu. Pogodaeva, Y.A. Semenov, O.F. Slabkowicz, "Peculiarities of consumer behavior in the information economy", Economic journal, vol. $28,2012$.

[16] V.S. Lopanova, "Methodological approaches to the study of the consumer services market", Vestnik ekonomicheskoy integratsii, vol. 8(65), 2013, pp. 91-100.

[17] Yu.D. Romanenko, A.F. Razin, S.V. Taktarova, "Interaction of subjects of the consumer market in the digital economy", Bulletin of Mari State University Series Agricultural Sciences, Economic Sciences, vol. 5(1), 2019, pp.106.

[18] Yu.V. Dorokhova, "Research approaches to consumer behavior in the system of social and economic relation", Central Russian Bulletin of social Sciences, vol. 4, 2010.

[19] A.V. Zverev, "Theoretical bases of modernization of regional consumer market", Finance. Economy. Strategy, vol. 3, 2011, pp. 42-47

[20] O.A. Shakhova, "The role of the consumer market in the development of socio-economic systems, the Economy of the region", The Economy of the region, vol. 4, 2008, pp. 175-180.

[21] L. Tsezuan, N. A Rukhmanova, "Conceptual and methodological approaches to the statistical study of the regional market of consumer goods and services", Scientific analytical journal Science and practice of the Russian economic University. G. V. Plekhanov, vol. 2(22), 2016, pp. 91-96. 
[26] A.A. Pshunetlev, "Systematic approach to the study of the regional consumer market", Management of economic systems: electronic scientific journal, vol. 4(64), 2014, p. 21.

sociology and dynamics of consumer behavior of Russians", Alley of science, vol. 5, 2017, pp. 198-201.

[23] D.I. Ermakov, consumer Research and consumer behavior, Law and state: theory and practice, 2014.

[24] A. Ilyin, A. Kukharchuk, "Adventures of marketing in Russia", Practical marketing, vol. 5, 2003.

[25] S.V Marichev., D.K. Rakhmatullina, "Transformation of system requirements in the modern economy", Actual problems of Economics and Law, vol. 2(22), 2012, pp. 5-10.

[27] D.A. Shevchenko, "Research of consumer behavior of large market segments in Russia: generational approach", Practical marketing, vol. 4(194), 2013, pp. 4-13.

[28] T. Stonier, The Wealth of Information. A Profile of the Post-Industrial Economy, 1983. 